\title{
FRAGTURES OF THE PATELLA
}

\author{
J. C. SCOTt, Oxford, England \\ Director of Orthopaedic Services of the Wingfield-Morris Orthopaedic Hospital, Oxford \\ Formerly Senior Specialist Royal Air Force Orthopaedic Service
}

The subject of fracture of the patella is one in which new interest has arisen during the last ten years because there has been much discussion as to whether or not good function of the knee joint is regained after excision of the bone. One school of thought, led by Brooke (1937) and supported by Watson-Jones (1945) and others, contends that excision of the patella leads to no appreciable weakening and gives a strong joint which is free from symptoms. Such protagonists pursue their belief to its logical conclusion by recommending removal of the patella for many types of fracture. The other school, which is more conservative and of which there are many supporters, believes that complete and accurate reconstruction of the patella after injury is likely to give a joint which will work as well as, and wear better than, one in which the normal anatomy has been disturbed by removal of a component part. The only way to settle this problem is by study of a long-term review of many cases, treated by various methods. In this series, 196 fractures of the patella were reviewed from one to five years after treatment. The patients had been treated in the orthopaedic service of the Royal Air Force, some from the beginning, and others only after initial treatment had been carried out elsewhere. The fact that a group of surgeons took part in treatment should enhance the value of the analysis by averaging such factors as judgment and technical skill.

The results have been examined after study of all information available from detailed R.A.F. clinical records and other Service sources, and from questionnaires which have been sent out. Having regard to the fact that the patients represented many nations, all over the world, the response has been good. The aim was to obtain a subjective view, and care was taken to make it clear that the investigation was in no way related to Service or Ministry of Pensions requirements.

It is of course obvious that not all fractures of the patella need operation. Many marginal and polar fractures, without separation, in which the articular cartilage is undamaged and the extension mechanism is intact-a group which accounted for 15 per cent. of the cases in this series-require no more than a brief period of protection. Indeed it would be wise to classify simple fractures of the patella not in relation to the anatomical type, but in relation to the degree of injury to articular cartilage and the damage to the quadriceps expansion. For example, a stellate fracture without displacement which is due to direct violence must almost certainly be associated with considerable injury to the articular cartilage of both patella and femur; whereas a transverse fracture without displacement which is due to indirect violence may be associated with little or no damage to the articular surfaces. Many surgeons would adopt the same treatment for both these groups of fracture, but clearly without good reason.

The treatment adopted in this series of 196 fractures was: excision of the whole bone, 101; excision of part of the bone, 33; open reduction and suture, 18; suture with later excision, 14; no operation, 30. These procedures have been investigated in relation to the type of fracture (Table I). Some fractures of the upper and lower thirds were transverse, but the majority were comminuted. Fractures in which the articular surface did not appear to be involved are described as "polar fractures." Thirty-seven were open fractures; twenty-five being treated by excision of the whole bone, six by excision of one fragment, one by suture and fixation, and five by no operation. 


\section{ANALYSIS OF IMMEDIATE TREATMENT AND RESULTS}

Since we are concerned primarily with the principles of treatment, all cases in which the result was influenced by unexpected complications have, so far as possible, been excluded. Such complications will be considered separately.

Excision for closed fractures-These cases have been divided into those operated upon during the first fourteen days, and those operated on later. In the first group the average period of post-operative immobilisation was just under four weeks. The average period of disability was four months, after which time all but one had full extension movement, and flexion movement to 90 degrees: two had full movement. In the second group, which were operated on later, the average post-operative immobilisation was four weeks, and the average total disability nearly six months. It would appear, therefore, after excluding the average pre-operative time, that patients operated on within the first fourteen days required one month less for recovery than those operated on after a longer interval.

TABLE I

Analysis of 196 Fractures of the Patella

Type of Fracture in relation to Operation performed (Type not stated in 24 Cases)

\begin{tabular}{|l|c|c|c|c|c|c|c|}
\hline & & $\begin{array}{c}\text { Comminuted } \\
\text { fracture }\end{array}$ & $\begin{array}{c}\text { Fracture } \\
\text { upper part }\end{array}$ & $\begin{array}{c}\text { Fracture } \\
\text { lower part }\end{array}$ & $\begin{array}{c}\text { Transverse } \\
\text { fracture }\end{array}$ & $\begin{array}{c}\text { Vertical } \\
\text { fracture }\end{array}$ & $\begin{array}{c}\text { Polar } \\
\text { fracture }\end{array}$ \\
\hline Excision of bone . & $\cdot$ & 46 & 5 & 26 & 13 & 1 & 0 \\
Excision one fragment & $\cdot$ & 1 & 6 & 14 & 0 & 7 & 5 \\
Suture and fixation & $\cdot$ & 0 & 1 & 11 & 6 & 0 & 0 \\
No operation . . & $\cdot$ & 3 & 2 & 3 & 4 & 5 & 13 \\
\hline
\end{tabular}

Excision for open fractures-A similar division was made into two groups. In all but two cases which were operated upon during the first fourteen days the excision was part of primary wound treatment. In these, the average period of post-operative immobilisation was three weeks, and the average disability period nearly five months. Eight regained full extension movement and 90 degrees or more of flexion movement; four had full movement. In the second group of compound fractures of the patella, where the bone was excised later than fourteen days, the average period elapsing between injury and excision was fourteen weeks. The average duration of post-operative immobilisation was five weeks, and the average total disability was eight and a half months. If the pre-operative loss of time is subtracted it leaves a disability time of just over five months. In this group, all regained full extension movement and 90 degrees or more of flexion movement; one had full movement. Excision of one fragment-Analysis of patients in whom one fragment was excised showed that the average disability period was nearly four months. All but one regained 90 degrees of flexion movement, and four out of seventeen had full movement. Those operated on after fourteen days showed a closely comparable period of post-operative disability (3.7 months as compared with 3.6 months); one had less than 90 degrees flexion movement and four out of ten had full movement.

Suture-Nearly all fractures treated by operative reduction and internal fixation, most of them transverse fractures, were operated on within the first fourteen days. The average period of post-operative immobilisation was six and a half weeks, and the average postoperative disability period five months. All regained full extension movement; and in all

VOL. 31 B, NO. 1, FEBRUARY 1949 
J. C. SCOTT

but one there was 90 degrees or more of flexion movement; six out of fourteen regained full movement. Table II summarises the analysis of post-operative periods of disability and immediate results.

If all patients in the series are grouped together it will be seen that, of those treated by operation, twenty-one regained full knee movement after an average period of immobilisation of 3.3 weeks and an average disability period of 14.3 weeks; as compared with the average immobilisation period in all groups of 4.4 weeks and the average disability period of 17 weeks. This gives a rough but fairly comprehensive picture of what can be expected from fractures of the patella treated on orthodox lines, assuming that there is no unforeseen complication of treatment.

TABLE II

Analysis of 118 Fractures of the Patella in WHich there WAS NO UNEXPECTED COMPLiCation OF TREATMENT

\begin{tabular}{|c|c|c|c|c|c|c|c|c|}
\hline & & & & $\begin{array}{c}\text { Number } \\
\text { of } \\
\text { cases }\end{array}$ & $\begin{array}{c}\text { Average } \\
\text { time of } \\
\text { immobilisa- } \\
\text { tion }\end{array}$ & $\begin{array}{c}\text { Average } \\
\text { time of } \\
\text { disability } \\
\text { (post-op.) }\end{array}$ & \multicolumn{2}{|l|}{ Range of movement } \\
\hline \multicolumn{4}{|c|}{ Excision of closed fractures- } & & Weeks & Months & & \\
\hline Before 14 days & . & - & $\cdot$ & 16 & $3 \cdot 75$ & $4 \cdot 0$ & $\begin{array}{l}\text { More than } 90^{\circ} \text { flexion } \\
\text { Full movement }\end{array}$ & $\begin{array}{r}15 \\
2\end{array}$ \\
\hline After 14 days & $\cdot$ & $\cdot$ & . & 12 & $4 \cdot 0$ & $5 \cdot 0$ & $\left\{\begin{array}{l}\text { More than } 90^{\circ} \text { flexion } \\
\text { Full movement }\end{array}\right.$ & $\begin{array}{r}11 \\
0\end{array}$ \\
\hline \multicolumn{9}{|c|}{ Excision of open fractures- } \\
\hline Before 14 days & & & . & 10 & $3 \cdot 1$ & $4 \cdot 8$ & $\begin{array}{l}\text { More than } 90^{\circ} \text { flexion } \\
\text { Full movement }\end{array}$ & $\begin{array}{l}8 \\
4\end{array}$ \\
\hline $\begin{array}{l}\text { After } 14 \text { days } \\
\text { (Average } 14 \mathrm{w}\end{array}$ & eeks & $\cdot$ & . & 9 & $5 \cdot 0$ & $5 \cdot 3$ & $\left\{\begin{array}{l}\text { More than } 90^{\circ} \text { flexion } \\
\text { Full movement }\end{array}\right.$ & $\begin{array}{l}9 \\
1\end{array}$ \\
\hline \multicolumn{9}{|c|}{ Excision of one fragment- } \\
\hline Before 14 days & - & . & - & 17 & $3 \cdot 8$ & $3 \cdot 6$ & $\begin{array}{l}\text { More than } 90^{\circ} \text { flexion } \\
\text { Full movement }\end{array}$ & $\begin{array}{r}16 \\
4\end{array}$ \\
\hline After 14 days & - & . & . & 10 & $4 \cdot 5$ & $3 \cdot 7$ & $\left\{\begin{array}{l}\text { More than } 90^{\circ} \text { flexion } \\
\text { Full movement }\end{array}\right.$ & $\begin{array}{l}9 \\
4\end{array}$ \\
\hline Suture of fragment & & · & - & 14 & $6 \cdot 5$ & $5 \cdot 0$ & $\left\{\begin{array}{l}\text { More than } 90^{\circ} \text { flexion } \\
\text { Full movement }\end{array}\right.$ & $\begin{array}{r}13 \\
6\end{array}$ \\
\hline No operation . & . & • & $\cdot$ & 30 & $4 \cdot 5$ & $2 \cdot 2$ & $\left\{\begin{array}{l}\text { More than } 90^{\circ} \text { flexion } \\
\text { Full movement }\end{array}\right.$ & $\begin{array}{l}30 \\
26\end{array}$ \\
\hline
\end{tabular}

In considering these figures it should be remembered that they are averages and therefore subject to variation. Nevertheless, I am advised that, statistically, the variation of disability between patients operated on before and after fourteen days appears to be significant.

\section{COMPLICATIONS DIRECTLY GONNEGTED WITH TREATMENT}

Complications directly associated with treatment included wound infection, peroneal palsy, thrombo-phlebitis, aseptic necrosis, refracture, and malunion. A certain number of cases have been excluded from this analysis by reason of other injuries such as fracture of the shaft of the femur of the same limb, fracture of the leg bones, extensive wounds or burns, which necessarily modified the treatment.

Wound infection-In the series of nearly two hundred operations, performed by many surgeons, there were nine cases of wound infection. In two, the infection was sufficient to cause ankylosis of the joint, one being a compound fracture treated by early excision of the wound and of the patella. In the other seven cases, infection outside the joint accounted only for delay in healing and slow recovery of function.

Peroneal palsy-Two patients suffered temporary peroneal palsy. 
Thrombo-phlebitis-One patient developed severe thrombo-phlebitis with pulmonary embolism, and after eight months he had a swollen shiny leg with a range of movement from 180 to 120 degrees.

Aseptic necrosis-Two patients in whom the fracture was fixed by a vitallium screw developed aseptic necrosis of the proximal fragment. One of these was treated by excision of the patella and repair of the quadriceps expansion.

Refracture and malunion-Two patients sustained refracture without displacement. The group of fourteen cases in which suture was followed by excision all showed early or late complications of suture. Four patellae were excised for refracture, from six weeks to twelve months after suture; five were excised for malunion with patello-femoral osteoarthritis, from seven months to six years after suture; two were excised early after bad reduction and wiring; one was excised for vascular changes after screwing; and in two, the reason was not stated.

\section{RESUlts AS ESTIMATEd BY THE PATIENTS}

The form of questionnaire, with analysis of the replies, is shown in Table III. The proportion of answers received was highest among those patients whose patellae had been excised-amounting to three-quarters of the total; it was lowest among those in whom no operation had been performed. The figures have been reduced to percentages for ease of comparison. Due caution must of course be exercised in comparing proportions of ninetythree patients treated by total or partial excision of the bone, with proportions of only twelve patients treated by open reduction, and eleven patients treated without operation. Indeed, with totals so small, the last two groups represent the least significant part of the inquiry. The figures from which definite conclusions can be drawn are the proportions of ninety-three patients who still complained of aching, pain, " giving way," and wasting, two years or more after excision of part or all the bone. Of seventy-one patients treated by total excision of the patella, thirty-five were reviewed more than three years, twenty more than four years, and sixteen more than five years after operation. So far as could be judged there was no evidence of improvement or deterioration between the second and the fifth years. The conclusion must be accepted, therefore, that after excision of the whole patella, or part of the patella, a high proportion of patients complain of persistent aching and discomfort ; and many have quite serious disability as represented by difficulty in running, working on ladders, and working in confined spaces. It is interesting to note that the number of patients who complained of "giving way" is almost exactly the same as the number who reported that there was wasting of the thigh. In most patients who replied to the questions, the range of movement was good although many failed to achieve the terminal degrees of flexion movement.

\section{DISCUSSION}

In this study it is the analysis of replies to the questionnaire which calls for emphasis. The immediate results are important; but if these are reasonably satisfactory-and Table II shows that they are-it is the long-term results in which we are most interested. When it is proposed to remove a fractured patella in a fit young man, it is well to know with some certainty how much disability is likely to remain. Table III gives a clear measure of this, and it needs no elaboration. It is evident that in most patients the disability is considerable. The findings do not bear out some claims which have been made in the past. This does not mean that the patella should never be excised; but it does mean that it should be excised only after careful deliberation.

In vertical or marginal fractures, all fractures without displacement, and polar fractures where the extensor mechanism is intact, no operative intervention is indicated. At the other extreme, only one treatment is indicated for fractures in which the whole bone is comminuted and the fragments are separated, and that is excision of the fragments with

VOL. 31 B, No. 1, FEBRUARY 1949 
suture of the extensor apparatus. Other varieties, lying between these extremes, call for much more thought. In eccentric fractures, whether transverse or comminuted, where more than half the bone and articular cartilage is intact, the small fragments should be removed and the quadriceps expansion or patellar tendon fixed to the main fragment. In central transverse fractures, open reduction and internal fixation is probably the best treatment, but only if reduction is accurate and fixation adequate. Unless it is possible to secure and to maintain anatomical reduction, excision is probably the better treatment. In open fractures the same principles apply, bearing in mind the primary importance of treatment of the wound.

TABLE III

Replies Received from 116 Patients to follow-UP Questionnaire

\begin{tabular}{|c|c|c|c|c|c|c|c|c|c|c|}
\hline \multicolumn{3}{|c|}{ All figures are percentages } & \multicolumn{2}{|c|}{$\begin{array}{l}\text { Excision } \\
\text { (71 cases) }\end{array}$} & \multicolumn{2}{|c|}{$\begin{array}{c}\text { Partial } \\
\text { excision } \\
(22 \text { cases })\end{array}$} & \multicolumn{2}{|c|}{$\begin{array}{l}\text { Reduction and } \\
\text { fixation } \\
(12 \text { cases })\end{array}$} & \multicolumn{2}{|c|}{$\begin{array}{l}\text { No operation } \\
\quad(11 \text { cases })\end{array}$} \\
\hline & & & Yes & No & Yes & No & Yes & No & Yes & No \\
\hline Is the knee normal? & . & . & 5 & 95 & 45 & 55 & 25 & 75 & 36 & 64 \\
\hline Does it ache? & . &.$\quad$. & 90 & 10 & 50 & 50 & 67 & 33 & 45 & 55 \\
\hline Does it pain? . . & . & . $\quad$. & 79 & 21 & 38 & 62 & 64 & 36 & 36 & 64 \\
\hline Does it get stiff? & . & $\cdot$. & 76 & 24 & 50 & 50 & 50 & 50 & 27 & 73 \\
\hline Does it swell? & . & . & 24 & 76 & 13 & 87 & 16 & 84 & 9 & 91 \\
\hline Does it give way? & . &.$\quad$. & 60 & 40 & 18 & 82 & 42 & 58 & 9 & 91 \\
\hline Can you fully straighte & $n ?$ & $\cdot \quad \cdot$ & 84 & 16 & 100 & 0 & 92 & 8 & 100 & $\mathbf{0}$ \\
\hline Is it straight on standir & ? & $\cdot \quad \cdot$ & 98 & 2 & 100 & 0 & 92 & 8 & 100 & 0 \\
\hline How near is heel to bu & ttock & $?$ & $\begin{array}{r}0^{\prime \prime}- \\
6^{\prime \prime}- \\
12^{\prime \prime}- \\
18^{\prime \prime+}\end{array}$ & $\begin{aligned} 6^{\prime \prime} & =16 \\
2^{\prime \prime} & =42 \\
8^{\prime \prime} & =34 \\
& =8\end{aligned}$ & $\begin{array}{c}0^{\prime \prime}- \\
6^{\prime \prime}-1 \\
12^{\prime \prime}-1 \\
18^{\prime \prime}+\end{array}$ & $\begin{array}{l}=36 \\
=50 \\
=10 \\
=4\end{array}$ & $\begin{array}{r}0^{\prime \prime}-6 \\
6^{\prime \prime}-12 \\
12^{\prime \prime}-18 \\
18^{\prime \prime}\end{array}$ & $\begin{array}{l}"=50 \\
"=0 \\
=50 \\
=0\end{array}$ & $\begin{array}{l}0^{\prime \prime}-6 \\
6^{\prime \prime}-12 \\
12^{\prime \prime}-18 \\
18^{\prime \prime}+\end{array}$ & $\begin{array}{l}=80 \\
=20 \\
=0 \\
=0\end{array}$ \\
\hline Is it wasted? & . & $\cdot$ & 60 & 40 & 36 & 64 & 50 & 50 & 9 & 91 \\
\hline Can you walk upstairs & norm & sally?. & 61 & 39 & 81 & 19 & 58 & 42 & 82 & 18 \\
\hline Can you walk downstair & s nor & rmally? & 45 & 55 & 66 & 34 & 33 & 66 & 82 & 18 \\
\hline Can you stand on one 1 & eg? & . & 90 & 10 & 100 & 0 & 66 & 33 & 100 & 0 \\
\hline How far walk without & liscon & mfort? & $\begin{array}{l}\frac{1}{2} \text { mile } \\
\frac{1}{2}-2 \mathrm{~m} \\
2-4 \mathrm{~m} \\
4 \mathrm{mile}\end{array}$ & $\begin{array}{r}=24 \\
\text { es }=39 \\
\text { es }=13 \\
+\quad=24\end{array}$ & $\begin{array}{l}\frac{1}{2} \mathrm{mile} \\
\frac{1}{2}-2 \mathrm{mi} \\
2-4 \mathrm{mi} \\
4 \mathrm{miles}\end{array}$ & $\begin{array}{r}=4 \\
\text { es }=8 \\
\mathrm{es}=8 \\
=80\end{array}$ & $\begin{array}{l}\frac{1}{2} \text { mile } \\
\frac{1}{2}-2 \text { mile } \\
2-4 \text { mile } \\
4 \text { miles }\end{array}$ & $\begin{array}{r}=33 \\
=25 \\
=9 \\
=33\end{array}$ & $\begin{array}{l}\frac{1}{2} \text { mile } \\
\frac{1}{2}-2 \text { mile } \\
2-4 \text { mile } \\
4 \text { miles }\end{array}$ & $\begin{array}{r}=9 \\
\text { es }=19 \\
\text { es }=9 \\
+=63\end{array}$ \\
\hline Can you run? & . & . & 50 & 50 & 77 & 23 & 33 & 66 & 91 & 9 \\
\hline Can you play games? & $\cdot$ & . & $\begin{array}{c}\text { Some } \\
44\end{array}$ & $\begin{array}{c}\text { None } \\
56\end{array}$ & $\underset{52}{\text { Some }}$ & $\begin{array}{c}\text { None } \\
48\end{array}$ & $\underset{25}{\text { Some }}$ & $\begin{array}{c}\text { None } \\
75\end{array}$ & $\begin{array}{c}\text { Some } \\
73\end{array}$ & $\begin{array}{c}\text { None } \\
27\end{array}$ \\
\hline Change of job?. & . & . & $\begin{array}{c}\text { Yes } \\
41\end{array}$ & $\begin{array}{c}\text { No } \\
59\end{array}$ & $\begin{array}{c}\text { Yes } \\
9\end{array}$ & $\begin{array}{l}\text { No } \\
91\end{array}$ & $\begin{array}{c}\text { Yes } \\
55\end{array}$ & $\begin{array}{l}\text { No } \\
45\end{array}$ & $\begin{array}{c}\text { Yes } \\
0\end{array}$ & $\begin{array}{l}\text { No } \\
100\end{array}$ \\
\hline
\end{tabular}

The second problem, solution of which may be assisted by the results of this investigation, is that of the best post-operative treatment. Analysis of these cases, treated by many surgeons, showed clearly that there was lack of agreement. In the Royal Air Force orthopaedic centres, post-operative immobilisation after excision varied from three to seven weeks. In cases in which the primary treatment had been carried out elsewhere the period varied from a few days in a bandage to three months in plaster. This is an important point, 
because if the period is too long there is much stiffness of the joint and protracted invalidity; whereas if it is too short, stretching or rupture of the tendon may make it necessary to perform another operation for secondary repair or shortening of the tendon. Review of these cases suggests that the best duration of post-operative immobilisation is from three to four weeks, during which time the patient should practise static quadriceps contraction, and may be allowed weight-bearing after the tenth day.

\section{SUMMARY}

1. A series of 196 fractures of the patella has been reviewed.

2. The treatment adopted was excision of the whole bone-101; excision of part of the bone-33; open reduction and suture-18; suture with later excision-14; no operation-30. 3. The average time of post-operative disability varied from 3.6 to $5 \cdot 3$ months. The time was appreciably less when operation was carried out before the fourteenth day than when it was done later.

4. An attempt was made to follow up, two to five years after injury, those patients in whom the result was not influenced by other major injuries of the limbs or by unexpected complications. Replies to questionnaires were received from 116 patients.

5. Of these, all regained a good range of movement, varying from 90 degrees of flexion to full movement, whether treatment was by excision of part or all the bone, or by open reduction and suture.

6. The late results of excision of the patella, as estimated by the patients themselves two to five years after treatment, showed that there was considerable residual disability.

7. After total excision of the bone only 5 per cent. of patients considered that the knee was normal; 90 per cent. complained of aching; 60 per cent. complained of " giving way." After excision of one fragment, about half the patients regarded the knee as normal and half complained of aching and stiffness.

8. The number of fractures in this series treated by accurate internal fixation was too small to make justifiable comparisons.

9. The indications for non-operative treatment, open reduction and accurate internal fixation, excision of one fragment, and excision of the whole bone are discussed.

10. Excision of part or all the patella is often inevitable, but some claims made in the past for the results of this operation are not substantiated.

\section{REFERENCES}

Brooke, R. (1937): British Journal of Surgery, 24, 733.

Walmsley, R., and Bruce, J. (1937): British Journal of Surgery, 25, 17.

WAtson-Jones, R. (1945): British Medical Journal, 2, 195.

Editor's comment-It is fair to say that this stimulating and provocative contribution has been published only after much discussion and some disagreement. Every article which is published in the Journal of Bone and Joint Surgery is subjected to close scrutiny and severe criticism, and this article has received its full share. The divergent views of members of the Editorial Board may perhaps best be summarised in relation to the sixth paragraph of the Summary, in which it is stated that " the late results of excision of the patella ... showed that there was considerable disability." The question that arises is whether such disability was attributable to excision of the bone, or whether it was the inevitable consequence of the original injury. Are we sure that after such injury the residual disability would have been less if the patella had been sutured and not excised?

VOL. $31 \mathrm{~B}$, NO. 1, FEBRUARY 1949 